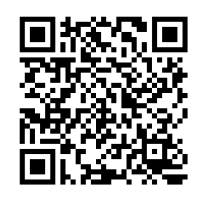

Keywords:

Artificial Intelligence

Systematic Review

Bibliometric Review

Multilayer Perceptron,

Forest Engineering Problems

Received 23/01/2019

Accepted 29/05/2019

+Correspondence:

flavio_chi@hotmail.com
Flávio Chiarello'+, Maria Teresinha Arns Steiner ${ }^{1 a}$, Edilson Batista de Oliveira ${ }^{2}$, Júlio Eduardo Arce ${ }^{3}$; Júlio César Ferreira'

\section{ARTIFICIAL NEURAL NETWORKS APPLIED IN FOREST BIOMETRICS AND MODELING: STATE OF THE ART (JANUARY/2007 TO JULY/2018)}

ChIARELlO, F.; STEINER, M. T. A.; OliVEIRA, E. B.; ARCE, J. E.; FERREIRA, J. C. Artificial Neural Networks Applied in Forest Biometrics and Modeling: State of the Art (January/2007 to July/20I8). CERNE, v. 25, n. 2, p. I40-I55, 2019.

\section{HIGHLIGHTS}

Artificial Intelligence and Artificial Neural Networks in Forest Engineering.

Systematic and Bibliometric Review: Science Direct, Scopus and Web of Science.

$32 \%$ of the analyzed papers predict the final total marketable volume.

$63 \%$ of the analyzed articles were from Brazilian researchers.

78\% making use of Multilayer Perceptron Networks (MLP).

$28 \%$ using Statistica software.

\section{ABSTRACT}

Artificial Intelligence has been an important support tool in different spheres of activity, enabling knowledge aggregation, process optimization and the application of methodologies capable of solving complex real problems. Despite focusing on a wide range of successful metrics, the Artificial Neural Network (ANN) approach, a technique similar to the central nervous system, has gained notoriety and relevance with regard to the classification of standards, intrinsic parameter estimates, remote sense, data mining and other possibilities. This article aims to conduct a systematic review, involving some bibliometric aspects, to detect the application of ANNs in the field of Forest Engineering, particularly in the prognosis of the essential parameters for forest inventory, analyzing the construction of the scopes, implementation of networks (type - classification), the software used and complementary techniques. Of the I, I 40 articles collected from three research databases (Science Direct, Scopus and Web of Science), 43 articles underwent these analyses. The results show that the number of works within this scope has increased continuously, with $32 \%$ of the analyzed articles predicting the final total marketable volume, $78 \%$ making use of Multilayer Perceptron Networks (MLP, Multilayer Perceptron) and $63 \%$ from Brazilian researchers. 


\section{INTRODUCTION}

The human brain has attributes that would be desirable in any artificial system. Its skills in dealing not only with probabilistic and/or inconsistent information in different situations, but also its flexibility to adapt to poorly defined situations, has attracted the attention of many scholars, who intensified their research in the field of artificial intelligence (Al) in the 1980s with the use of intensive computing.

The dissemination of the methodologies found in this field has achieved interesting results in different areas of knowledge. In forestry, the Artificial Neural Network (ANNs) technique is considered a promising and very efficient alternative for defining the best management of forest resources (Menzies et al., 2007; Bhering et al., 2015; Miguel et al., 2015; Ribeiro et al., 2016 and Çatal \& Saplioğlu, 2018]).

Studies guarantee that in different scenarios ANNs have contributed to high performance compared with classical regression models. Their purely massive structure, distributed (in layers) and ability to learn and generalize situations, tolerance of flaws and noises, and their flexibility in modeling categorical (qualitative) and numerical variables provide the methodology with a favorable context regarding the capacity to solve problems of any size (Binoti et al., (2013).

The wide range of spectra allows the evaluation of different network configurations based on alterations to the input data, number of neurons in the hidden layer, the output feedback (as input signals for the next iteration) or weight adjustments. Consequently, ANNs allow the finding of feasible solutions in the search space, even with small, but well balanced, population samples.

The need to develop studies and analyses for the parameterization and adaptation to different scenarios, such as final volume prediction, basal area, dominant height or growth and production of forest plantations (Binoti, 20I4), has attributed a high potential to ANNs, particularly with regard to the variables and phenomena modeling, which are considered complex. Studies in this line of research, such as those conducted by Diamantopoulou et al. (2009); Özçelik et al. (20I0); Soares et al. (20I I) and Binoti et al. (2017), have been considered relevant to the applications that occur in forestry science.

The significant increase in scientific content, not only in the field of forestry, but also in several others, has shown that the development of syntheses that facilitate access to this information (forecasting of intrinsic variables) is urgently needed. In other words, its idealization has enabled the formation of conclusions based on a combination of results from numerous sources. Thus, we can define a systematic review as a process that compiles and clusters a series of works (or studies) related to one or more topics based on the focused, welldefined investigative approach, which defines criteria on the identification, selection, assessment and synthesis of relevant information for conducting research.

Researchers have recently shown a strong tendency to conduct systematic and/or bibliometric literature reviews. Studies of this kind, although secondary, not only allow the expansion of knowledge but also address different relevant prisms and perspectives of themes of the same nature.

Considering these premises, unlike analogous works (with the same semantic), this article prioritizes the construction of a holistic view behind articles related to the application of ANNs in the field of forest sciences based on a detailed systematic review plan involving some bibliometric aspects. In other words, it seeks to clarify very important points on which to base the knowledge and directives that can support or not support the notion that the methodology can be viewed as promising. For this purpose, a survey of scientific articles was conducted by analyzing the construction of their respective scopes, verifying the form of implementation of ANNs (type (classification), architecture, configurations, computational language), data stratification, sample size, complementary techniques and findings.

The study is structured into five sections, including introduction. Section 2 presents the concept of ANNs, their applications and some relevant aspects regarding systematic and bibliometric literature reviews. The methodological procedure used in the study is outlined in Section 3. The results are presented and discussed in Section 4. The conclusions of the study are given in Section 5 .

\section{THEORETICAL FOUNDATION}

The theoretical foundation is based on two approaches. First, the study briefly discusses the concept of Bibliometric and Systematic Literature Reviews. This is followed by the contextualization and a detailed description of what constitutes an ANN. The functioning of an artificial neuron is explained, and the main implementation algorithm for network learning/training, backpropagation, is presented.

\section{Systematic Literature Review}

Galvão and Pereira (2015) claimed that systematic reviews should be made available so that other researchers can repeat the applied methodological procedure and that their search criteria need to be comprehensive and free of bias. 
Normally, the development of this type of review establishes a relatively solid pattern in the search for works and ends up being modified according to the researcher's needs or the field under study. Although a sequence of steps should be followed, there is, in fact, no single rule for the definition of the search criteria or the way in which the search will be directed.

As pointed out by Medeiros et al. (20I5), the Bibliometric Literature Review can be understood as a purely investigative action that focuses on issues that are similar to the one being addressed. For this reason, it is considered one of the initial steps of the scientific method (applied to avoid any possibility of duplication in studies).

As a contribution, Gil (2002) emphasized that this classic approach to analyzing (or assessing) a review is intended to allow researchers much greater coverage/ measurement of the indexes oriented to the production and dissemination of relevant subjects than pragmatic, i.e., direct research.

\section{Artificial Neural Networks}

The first study of neurocomputation dates back to 1943, when the physiologist McCulloch and the mathematician Pitts developed a pioneer work, which consisted of assimilating the behavior of biological neurons as a binary circuit for the creation of a corresponding mathematical model. Despite its ability to separate two Boolean inputs, this model was not able to perform the learning process, since it did not have free parameters (Aguiar, 2010).

Years later, more precisely in 1949, the neuropsychologist Donald Hebb made his great contribution to the McCulloch and Pitts' model. In brief, Hebb's projects had as a guideline the creation of a specific learning law for the synapse of neurons, demonstrating that the competence of ANNs is the result of altered synaptic efficiency (ALMEIDA, 200I).

Despite the considerable reductions in related research, ANNs reached their peak in 1980. With the advent of computers with greater calculation processing capacity, Rumelhart, Hinton and Williams formalized the development of the back-propagation algorithm. (Rumelhart et al., 1986). This new approach provided the training of Multilayer Perceptron (MLP) networks with great generalization power, opening up new areas of implementation, which until then were only idealized (Freiman, 2004).

We can observe an ANN as a complex system of massively distributed data processing that aims to simulate the functions of the neurons in the human brain based on mathematical values or equations (Diamantopoulou et al., 2009). This traditional computational tool is capable of obtaining excellent results in different areas and applications, as described in the work of Oliveira et al. (2015) and Steiner et al. (2006), regarding bank lending through clients' classification (defaulters or paying customers). Other works in this respect are those of Valente et al. (20l4), concerning solving problems involving adulteration in the milk manufacturing process, and Gonçalves et al. (2016) on the classification of forest strata, based on remote sense data. These are just some of the practical examples that could be mentioned.

According to Haykin (200I), the ANN structure assumes a classical behavior of systems based on interconnected neurons, responsible for the basic processing of information/knowledge acquired by the network. This process occurs mainly due to the learning procedures and the connecting forces between the neurons, called synaptic weights, as shown in Figure I.

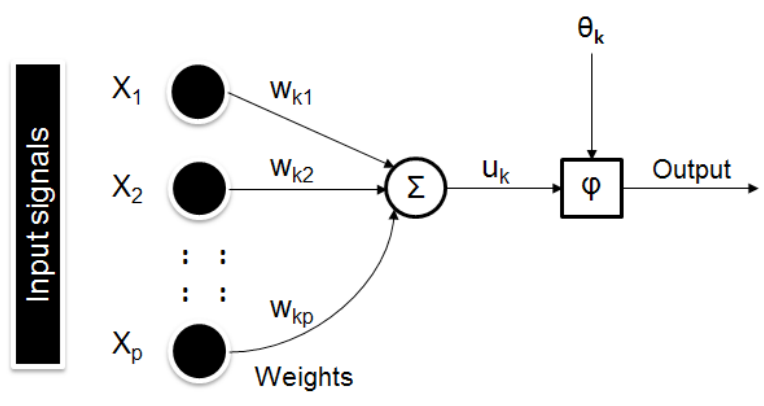

FIGURE I Description of the k-th neuron.

In Figure $I, x_{1}, x_{2}, \ldots, x_{p}$ corresponds to the process inputs, usually associated with the previous neuron output. The synaptic weights, $w_{k l}, w_{k 2}, \ldots, w_{k p}$ represent, in synthesis, the network memory, from the experience acquired through the presentations of the patterns. The sum symbolizes the linear combination process. In other words, it is responsible for producing an activation potential based on the sum of the input signals, weighted with their respective synaptic weights. The activation function $\varphi$ is observed as an output saturator from the neurons $\left(u_{k}\right)$, restricting their amplitude to a finite value $y_{k}$, usually normalized in the closed interval of $[0,1]$. Finally, the parameter $\theta$, or limit value (threshold), has the characteristic to help the ANN to adjust to the knowledge provided.

In general, ANN models are defined by the network topology, the node features, training type, and learning rules which, in addition to specifying an initial set of weights, indicate how these weights (or parameters) must be adapted, so that the performance of the networks is the best possible. According to Diamantopoulou et al. 
(2009), the design procedures and the training algorithm definitions are widely discussed and, therefore, they add value to many researches' development.

Although there are numerous learning algorithms, the most well-known and commonly used algorithm is the back-propagation algorithm, a method with a supervised paradigm that operates in two consecutive stages, feeding the network (forward propagation) and back-propagating the error (backward propagation) (Rumelhart et al. 1986; Fausett 1994 and Silva 2009).

As a contribution, Silva (2009) guarantees that this algorithm pragmatic character is directed to make the application of a set of inputs able to produce the desired or, at least, consistent, outputs. In theory, this is due to the gradual convergence of the network weights, so that the application of the input vectors can produce the necessary outputs.

\section{MATERIAL AND METHODS}

In order to formalize all the important conditions for a successful review, the present study adopted, a priori, the interpretation of the subjects that are considered relevant and that could serve as a basis for the development of the following research question: what advances were made in the field of forestry regarding the use of the ANN methodology for the prediction, prognosis or estimation of variables for its management?

In order to answer this question, a pilot study was conducted with different terms, followed by a logical AND or OR operator to find out which search format would be the most convenient in the following search bases: Science Direct, Scopus and Web of Science. The preliminary analysis showed that most of the authors reject the manipulation of derivations or very specific terminologies in the field of forestry, particularly with regard to the titles, abstracts or keywords, since the research space and, consequently, the index of the articles found, were relatively low.

The search filters were adjusted to refine the search, especially regarding the date of submission, document type and language (to check the progress in the field in national and international scenarios).

Thus, the prerogatives obtained by the several experiments were described by identifying the best configuration in the search terms, which delimits the selection of articles to the maximum, as shown in Figure 2.

Figure 2 shows that the preliminary search surveyed I, 140 articles in the three databases, of which 465 were from Scopus, 557 from the Web of Science and I I 8 from Science Direct up to the end of July 2018. However, the subsequent step was directed towards preparing an activity that could offer a solution to separating the articles based on their relevance. To do this, we conducted a survey of these works by applying a selection criterion processed in steps I and 2 (defined below) and in the exclusion of duplicate articles.

Theoretically, although different steps are considered, their natures encompass the same objective, i.e., they are responsible for weighing - by title (Step I) or abstract (Step 2, analyzed when only the title does not allow us to decide whether the subject is of interest) the works of interest (or not) to the research in question.

\section{Searchterms:}

(Artificial AND Neural AND Network) AND (Volume OR area OR diameter OR height OR Mortality) AND (Forest OR Pinus OR Silviculture OR Eucalyptus OR Thinning).

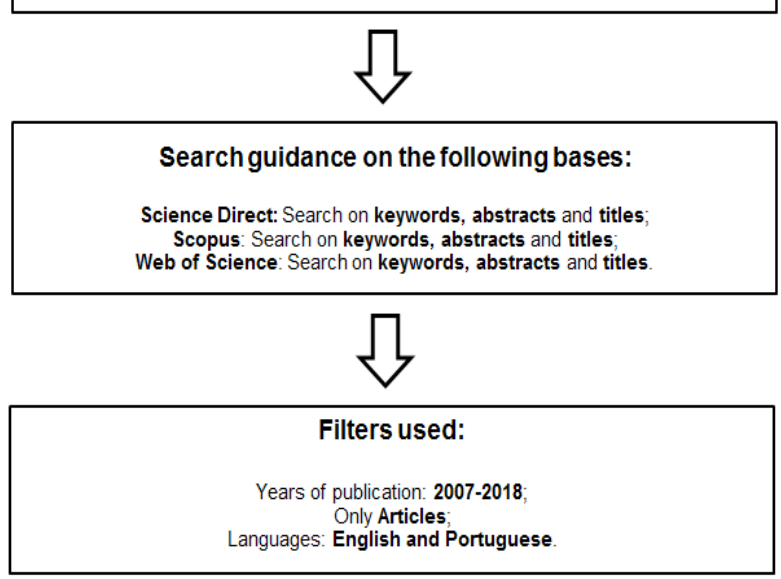

FIGURE 2 Methodology applied to Systematic and Bibliometric Reviews.

Despite these assumptions, it is important to emphasize that, on various occasions, the reading of the abstracts (step 2) was unnecessary, since the paper title did not present any kind of analogy or relation to the study's subject, such as forensic context, population growth, landslides in urban areas, electrocardiograms, $X$-ray examinations, limb fractures, innovations in the clean energy sector, climate changes, density patterns, possibility of radiation, bleeding problems, and hurricane forecasting.

Theoretically, with the execution of the first step, 636 articles guided the survey and, with the exclusion of duplicate articles (using Excel 2010) the final set contained 438 articles for a more detailed analysis (step 2 ) to identify those that could actually contribute to the study. With these definitions, 43 works were filtered up to July 2018 , serving as a basis for conducting the surveys of the main themes in each article: definition of their scope, the software used, classification of ANNs, activation functions, validation methods, authors by country, complementary techniques (applied cases), filiations, main journals and findings. Some of these alignments can be viewed in Figure 3. 


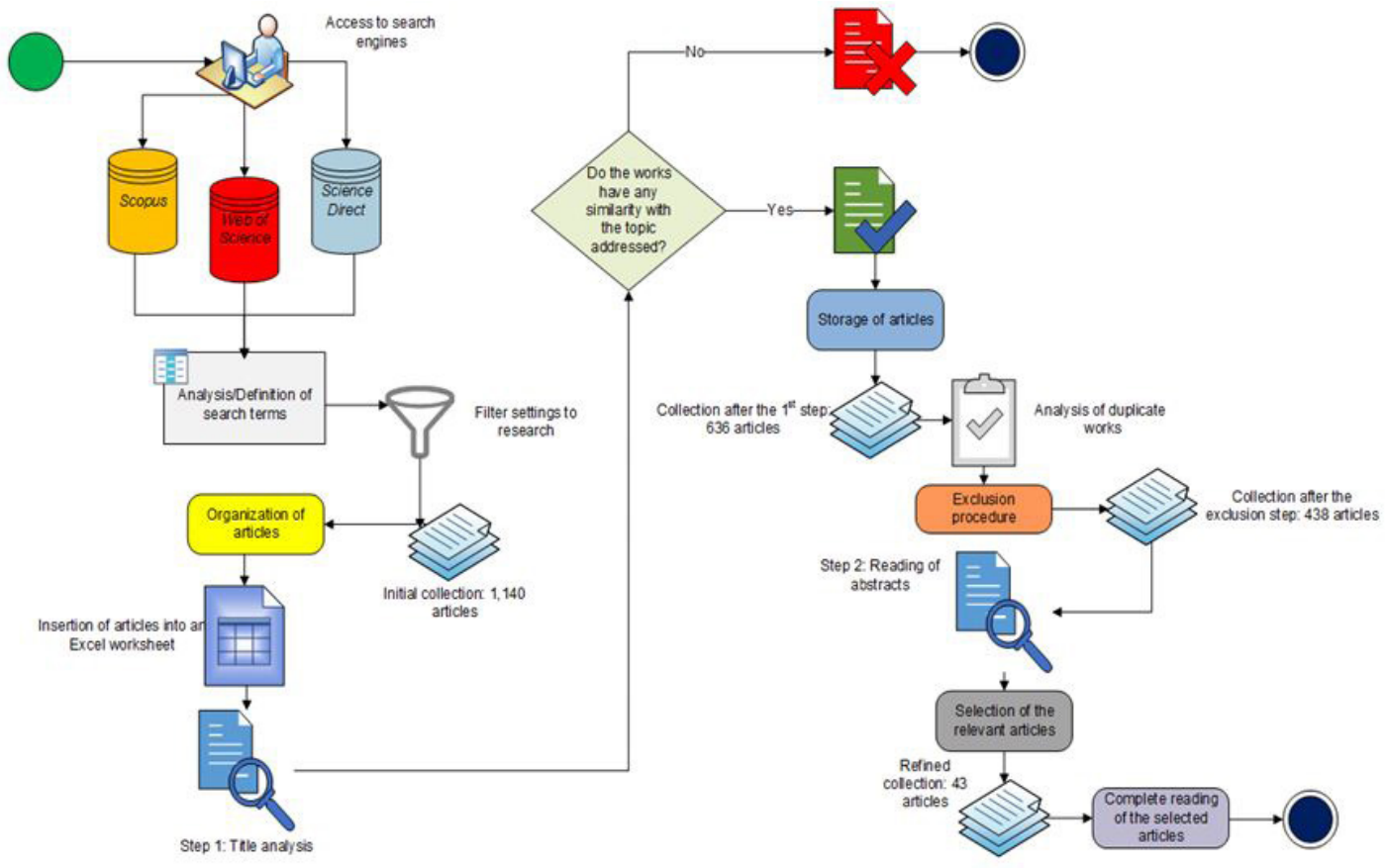

FIGURE 3 Criteria for filtering the 43 related articles.

\section{RESULTS AND DISCUSSION}

Initially, the analysis focused on the production of published articles, with emphasis on the application of ANNs in the forest context. As can be seen in Figure 4, there was a slight rise in the first years (up to 20I2), with some stationary periods $(2009,20 \mathrm{II}$ and $20 \mathrm{I} 2$, with only two publications), and more significant production in the last 6 years, with emphasis on the eight publications in 2015 and five new works up to July of 2018 , when this research was conducted. This growth is associated with interest in the field, the availability of databases, new software and updated packages, with different functional techniques, often distributed free of charge.

Considering the interpretation of the objectives proposed by each author, some authors chose to deepen their studies with more than one aim, often due to the

Number of publications (Jan/2007 - July/2018)

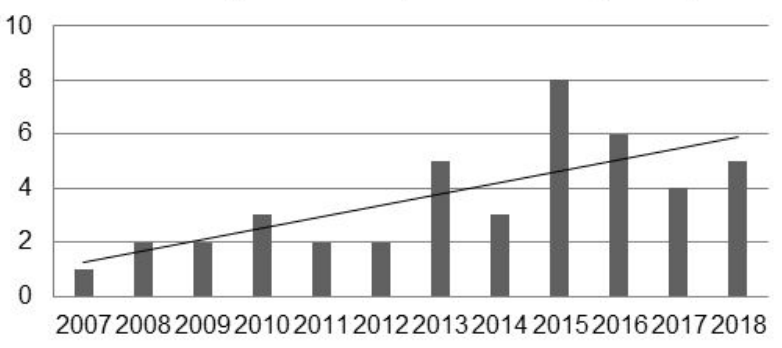

FIGURE 4 The 43 forestry publications analyzed and their publication years. possibility of finding an alternative tool to the traditional techniques or models that are frequently used in the forest scenario. Of these, we can mention Castro et al. (20/3), whose objectives addressed the issue of Mortality, DBH (Diameter at Breast Height) and Total Height. Others include Ashraf et al. (20I5) and Binoti et al. (20I5), who worked with the Volume Increase and Basal Area, and Miguel et al. (20I5), who worked with Volume and Final Height. Nunes and Gorgens (2016) conducted a study on Volume and Diameter, and Vieira et al. (2018) dealt with Growth and Future Height.

In the same circumstances, we can highlight that the most addressed scope of the whole sample was the prediction (prognosis) of the total final volume of marketable wood ( $32 \%$ of the works). Figure 5 presents the integration of all the information into a relationship format (Author-Objectives).

Despite the orientation towards ANNs, 3 I articles included the application of a complementary technique, be it of Linear Regression (37\%), Cellular Automata (7\%) or Kalman filter (13\%) (procedure incorporated to networks), as shown in Figure 6. Other approaches, such as Volumetric Equations, Random Forest, the Support Vector Machine (SVM), Least Squares, Individual-tree Models and the Image Segmentation technique, were also applied, but only once. Therefore, they are aggregated as "other techniques", accounting for $43 \%$ of the total.

Another premise of this study involved identifying the most frequently applied types of ANN to solve the 


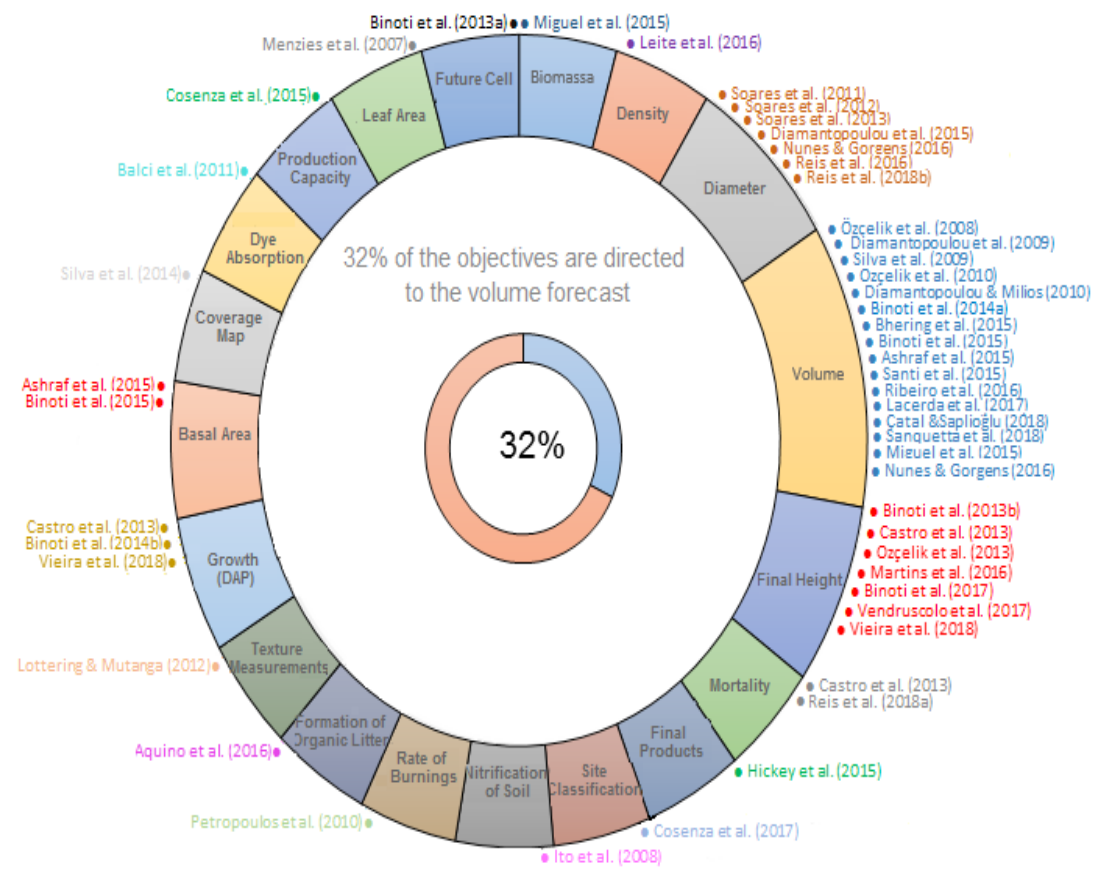

FIGURE 5 Relationships (Author-Objectives) of the 43 articles selected.

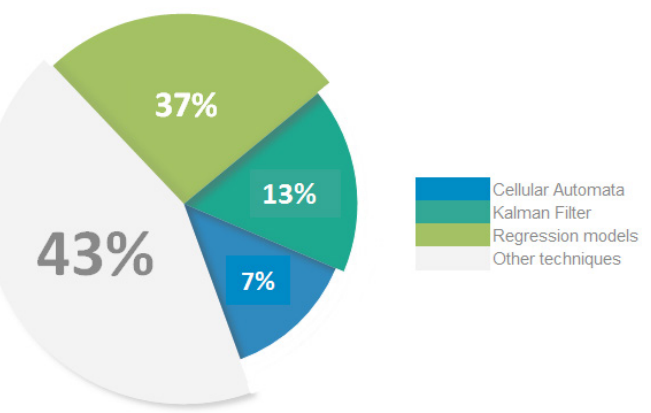

FIGURE 6 Complementary techniques addressed by the 31 (out of 43) articles that used more than one technique.

problems. With five different classifications at the end of the research, the authors' preference (Figure 7) was restricted to the classical Multilayer Perceptron (MLP) model with $78 \%$ of the total, followed by the Radial Basis Functions (RBF) with 13\%, the Cascade Correlation Artificial Neural Network (CCANN) - a model considered promising for achieving satisfactory results in the total volume prognosis, according to Diamantopoulou \& Milios (2010) — with 7\%, and fuzzy logic networks and the Single Layer Perceptron, with $1 \%$ each.

In addition to the panorama that was identified, another item of information was extracted regarding the use of ANNs, namely the type of activation function employed in their respective input and output layers. Although there are different types (or mathematical components), most authors (I5 in total) chose to use the Hyperbolic Tangent, followed

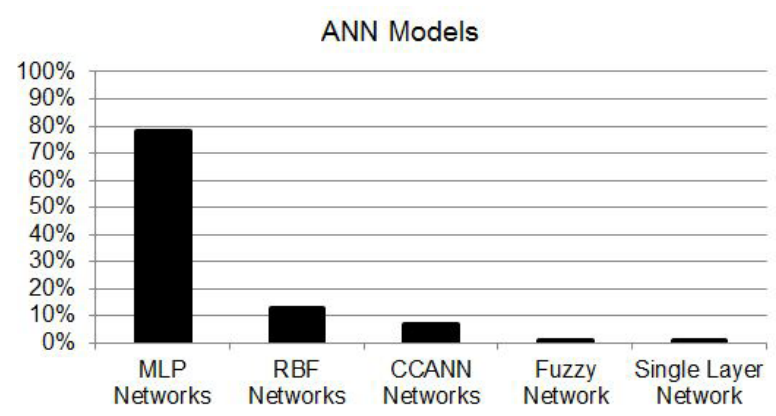

FIGURE 7 CANN models most used in the 43 studies.

by the Sigmoid or Sigmoidal function (I I), Logistics (10), Linear and Exponential (5), Sigmoidal Tangent (4), Sine and Identity (3), Softmax and Log (2), others (I). There were 13 unspecified (uninformed) works, as shown in Figure 8.

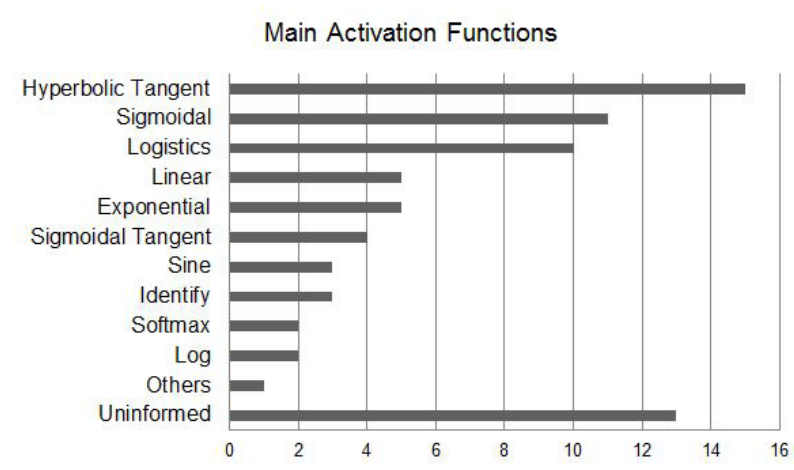

FIGURE 8 Main activation functions used in the 43 articles. 
Regarding the application of the validation (or verification) methods of the ability of ANNs to predict the expected results successfully, Figure 9 shows that the correlation coefficient was the main criterion adopted by the authors (2I times), followed by Root Mean Square Error (RMSE) with 20, \%RMSE (9), Bias (9), Mean Absolute Error (7), Histograms and Graphical Residue Analysis (6), Mean Error and Mean Square Error (5), Standard Error (4), Relative Error, Maximum Absolute Error and Coefficient of Determination (3), Statistical Test (L\&O), Efficiency Models, Error Matrix, Akaike Information Criterion, Kappa Coefficient and the \%Absolute Deviation totaled (2) and the "Other" class had only a single application.

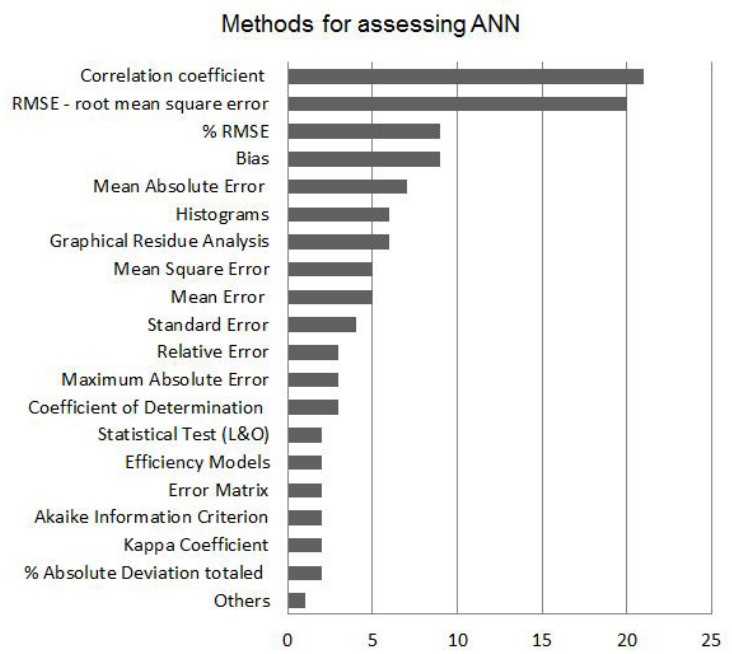

FIGURE 9 Methods used for assessing the ANNs in the 43 articles.

In addressing the researchers' nationality (Figure 10), Brazil was the main motivator in the development of articles in this line of research, responsible for $63 \%$ of the total. Brazil was followed by Turkey with I2\%, Greece with $10 \%$ and, with 3\%, South Africa, the USA, England, Ireland and Japan. The Federal University of Viçosa, Brazil, was the institution with the largest number of publications, a total of eight.

The analysis of the computational procedures for ANN implementation and execution showed that the most used interface was Statistica software, in 12 works, followed by Matlab (8), NeuroForest (7), R Software (2), WEKA - Waikato Environment for Knowledge Analysis - (I), ENVI - Environment for Visualizing Images - (I), JavaNNS - Java Neural Network Simulator - (I) and uninformed (II). However, it is worth noting that the different versions or derivations of the same package/program were not considered different operating systems, such as Statistica (7, I0 and I2) or Matlab (r20IOa, r20I3a and r20I6b). These data are shown in figure II.
Authors Per Country

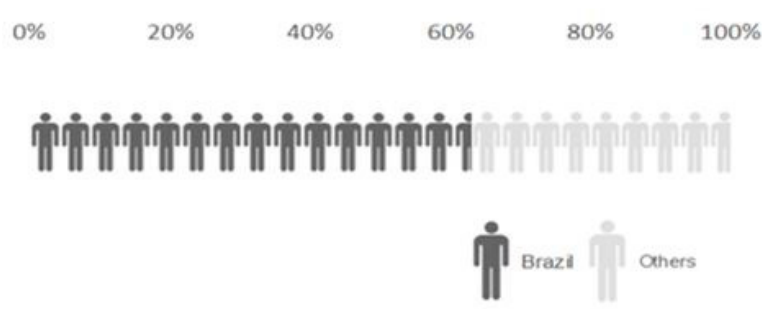

FIGURE 10 Geographical distribution of the 43 papers, involving several authors.

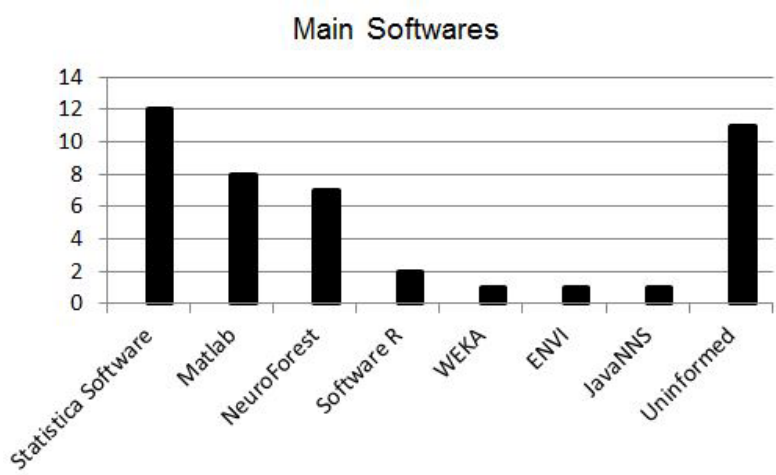

FIGURE I I Software used to implement the language used in the 43 analyzed works s.

In relation to the main journals, Table I shows that "Revista Árvore" and "Cerne" are considered the main journals, containing 6 and 5 published articles, respectively. On the other hand, the class designated as "Other" comprises a long list of journals with only one article, including Applied Ecology and Environmental Research, Applied Soft Computing Journal, Computers and Electronics in Agriculture, Comunicata Scientiae, Crop Breeding and Applied Biotechnology, Ecological Engineering, Ecological Modelling, European Journal of Remote Sensing, Expert Systems with Applications, Floresta, Forest Products Journal, Forest Science, GIScience \& Remote Sensing, Journal of Environmental Management, Journal of Spatial Sience, Nativa, Natural Resource Modeling, Neural Computing and Applications, Revista Brasileira de Ciências Agrárias, Science of the Total Environment, Sensors and Southern Forests.

TABLE I Descriptive statistics of the data groups.

\begin{tabular}{cc}
\hline Journals & Quantity \\
\hline Revista Arvore & 6 \\
Cerne & 5 \\
Biosystems Engineering, Forest Ecology and Management, & \\
$\begin{array}{c}\text { Pesquisa Agropecuária Brasileira, PlosOne and Scientia } \\
\text { Forestalis/Forest Sciences }\end{array}$ & 2 \\
\hline Other & I \\
\hline
\end{tabular}

To complement the information presented in Table I, Table 2 shows, in perspective, the institutions that participated in the survey. In short, the Federal 
University of Viçosa, located in the state of Minas Gerais, is the one that contributed the most, comprising 8 publications, followed by Süleyman Demirel University and the Federal University of Jequitinhonha and Mucuri Valleys, with 5 and 4 publications, respectively. The "Other" class consists of Arid Agriculture University, Cukurova University, Forestry and Forest Products Research Institute, Indiana University, Institute of Applied Physics, Federal University of Jequitinhonha and Mucuri, Federal University of Lavras, Federal University of Mato Grosso, Federal University of Espírito Santo, Federal University of Western Pará, Federal University of Paraná, University College Dublin, University of Bristol, University of Cambridge, University of KwaZulu-Natal and University of Lisbon.

Analyzing the conclusions of the studies, it can be said that all the information aided the development and execution of experiments to assess the capacity of ANNs in different contexts (scenarios and objectives). In general, all 43 studies showed that ANNs achieved satisfactory results (due to relatively low errors) and, therefore, can be considered a very efficient and accurate alternative in the prognosis of intrinsic variables in the forest inventory.

TABLE 2 Main affiliations found in the sample of 43 articles.

\begin{tabular}{cc}
\hline Affiliation & Quantity \\
\hline Federal University of Viçosa & 8 \\
\hline Federal University of Jequitinhonha and Mucuri Valleys & 5 \\
\hline $\begin{array}{c}\text { Süleyman Demirel University } \\
\text { Aristotle University of Thessaloniki, University of Brasília } \\
\text { and Federal University of Goiás }\end{array}$ & 3 \\
\hline Mamirauá Sustainable Development Institute & 2 \\
\hline Others & 1 \\
\hline
\end{tabular}

Detailed information on the Brazilian institutions, main researchers at these institutions, types of study and number of publications is shown in Table 3.
Assuming that there are many other data and/or elementary information regarding the articles analyzed in this study, Table 4 provides a clear and organized summary of this content.

\section{CONCLUSION}

Due to the great rise of Artificial Intelligence in the various fields of research and development, this study portrayed the construction and development of a systematic review, involving bibliometric aspects, orientated to identify the application of ANNs in different areas of the forest context, especially in forest biometry and modeling, more specifically, in the prediction of parameters considered important, from January 2007 to July 2018.

For this purpose, a methodological procedure was developed to scan articles in three research databases (Science Direct, Scopus and Web of Science), defining the main search terms (from a pilot study), filter selection and the exclusion of studies considered to be of no relevance and/or duplicated. Thus, at the end of the last step, 43 articles were selected, enabling the stratification of aggregating information for the study.

The variations in scope showed that advances were made in several respects, but the predominant one is estimating total marketable volume, making use of ANNs (especially the MLP network topology) and comparing them frequently with the traditional regression models. The results show that the number of works within this scope (volume) has increased continuously, with $32 \%$ of the analyzed articles predicting final total marketable volume (Figure 5), 78\% making use of Multilayer Perceptron Networks (MLP; Figure 7), $28 \%$ using Statistica software (Figure II) and 63\% from Brazilian researchers (Tables 2 and 3).

TABLE 3 Brazilian affiliations and other information found in the sample of 43 articles.

\begin{tabular}{|c|c|c|c|}
\hline Affiliation & Themes of the studies & Authors & Quantity \\
\hline Federal University of Viçosa & $\begin{array}{l}\text { Eucalyptus clone plantations (7); Managed forest in } \\
\text { the Amazon (I). }\end{array}$ & $\begin{array}{l}\text { Silva (2009); Binoti (20I3a); Binoti } \\
\text { (20।3b); Bhering (20I5); Cosenza (20I5); } \\
\text { Leite (20।6); Reis (20।6); Binoti (20I7). }\end{array}$ & 8 \\
\hline Federal University of Vales do Jequitinhonha and Mucuri & Eucalyptus plantations (hybrid or clone). & $\begin{array}{l}\text { Binoti (20|4a); Binoti (20|4b); Binoti } \\
\text { (20|5); Martins (20|6); Lacerda (20|7). }\end{array}$ & 5 \\
\hline Federal University of Goiás & Eucalyptus clone plantations. & $\begin{array}{l}\text { Soares (20II); Soares (20I2); Soares } \\
\qquad(20 \mid 3) .\end{array}$ & 3 \\
\hline University of Brasília & $\begin{array}{l}\text { Disposal of Plant Litter (I); Commercial Eucalyptus } \\
\text { Plantations (I); Biomass in the Cerrado region (I). }\end{array}$ & $\begin{array}{c}\text { Miguel (20I5); Castro (20I3); Aquino } \\
\text { (2016). }\end{array}$ & 3 \\
\hline Mamirauá Sustainable Development Institute & Amazon Forest. & Reis (20।8a); Reis (20।8b). & 2 \\
\hline Federal University of Mato Grosso & Tectona grandis trees. & Vendruscolo (2017). & $\mathrm{I}$ \\
\hline Federal University of Lavras & Soil Coverage in Minas Gerais State. & Silva (20|4). & $\mathrm{I}$ \\
\hline Federal University of Paraná & Cryptomeria japonica. & Sanquetta (20|8). & $\mathrm{I}$ \\
\hline Federal University of Espírito Santo & Eucalyptus. & Vieira (2018). & I \\
\hline Federal University of *Western Pará & Tapajós National Forest. & Ribeiro (2016). & 1 \\
\hline
\end{tabular}


TABLE 4 Detailed description of relevant data/information regarding the survey of the 43 articles selected by the sample.

\begin{tabular}{|c|c|c|c|}
\hline Publication & Intended Purpose(s) & $\begin{array}{l}\text { Number of networks that authors } \\
\text { have implemented }\end{array}$ & Identification of the Network Inputs and Outputs \\
\hline $\begin{array}{c}\text { Menzies et al. } \\
(2007)\end{array}$ & $\begin{array}{l}\text { The main idea of the paper was to predict } \\
\text { environmental degradation by measuring the } \\
\text { leaf area index (LAl) values using the Multiple } \\
\text { Regression and ANN techniques, and then creating } \\
\text { a comparative analysis to identify the best method. }\end{array}$ & $\begin{array}{c}4 \mathrm{MLP} \text { networks (I for each } \\
\text { assessed class). }\end{array}$ & $\begin{array}{l}\text { "The network inputs considered distinct parameters for } \\
\text { each developed class. Class I: coverage types, urban land, } \\
\text { pasture, cultivated fields, water and vegetation. Class 2: } \\
\text { lnitial and intermediate secondary succession. Class 3: Adult } \\
\text { forests and advanced succession. Class 4: Adult forests. } \\
\text { Output: Foliar area" }\end{array}$ \\
\hline Ito et al (2008) & $\begin{array}{l}\text { The proposal was to develop ANN models for the } \\
\text { prediction of soil nitrification potential (with the } \\
\text { owest number of physicochemical properties as t } \\
\text { input data) and, later, to compare their results with } \\
\text { the Multiple Linear Regression models. }\end{array}$ & $\begin{array}{l}\text { The study tested different } \\
\text { configurations in order to compare } \\
\text { the model predictive performance. } \\
\text { However, through a decision tree, } \\
\text { it trained } 5 \text { different networks. }\end{array}$ & $\begin{array}{llll}\text { "Inputs: Carbon-nitrogen ratio, } & \text { maximum } & \text { water } \\
\text { retention capacity and water } & \text { saturation } & \text { ratio. } \\
\text { Output: Soil nitrification potential." } & & \end{array}$ \\
\hline $\begin{array}{l}\text { Özçelik et al. } \\
(2008)\end{array}$ & $\begin{array}{l}\text { This study's objective was to test the performance of } \\
\text { a standard volume formula (using the Huber method } \\
\text { and local volume tables), as well as several other } \\
\text { techniques, including the modeling of the CCANN } \\
\text { network, to predict the tree stem volume, from three } \\
\text { species in the Mediterranean region of Turkey. }\end{array}$ & $\begin{array}{l}\text { The final study included two } \\
\text { CCANN networks for each of } \\
\text { the three assessed species. }\end{array}$ & $\begin{array}{l}\text { "Inputs: Stub diameter and the stem length for } \\
\text { the CCANN I network, and the CCANN II } \\
\text { network counted on the stub diameter, diameter } \\
\text { at the top of the tree trunk and the stem length. } \\
\text { Output: Volume." }\end{array}$ \\
\hline $\begin{array}{c}\text { Diamantopoulou } \\
\text { et al. (2009) }\end{array}$ & $\begin{array}{l}\text { This study's perspective work turned not only to } \\
\text { the development of volume equations for the Pinus } \\
\text { brutia stems, addressing the ANN techniques, } \\
\text { but also to demonstrate the application of an } \\
\text { alternative methodology in the field of reforestation } \\
\text { project, responsible for allowing the estimate and } \\
\text { optimization of the volume of dominant tree stems } \\
\text { in reforestation (using factors easily measurable in } \\
\text { the local and in the competition). }\end{array}$ & $\begin{array}{c}2 \text { Networks: one MLP and one } \\
\text { CCANN }\end{array}$ & $\begin{array}{l}\text { "Inputs: Both the MLP network and the CCANN network } \\
\text { were associated with four variables: density (correlated } \\
\text { with competition) and and the conditions related to the site } \\
\text { factor (altitude, exposure and inclination/slope). } \\
\text { Output: Volume." }\end{array}$ \\
\hline Silva et al. (2009) & $\begin{array}{l}\text { The first objective underwent the fitting assessment } \\
\text { of Schumacher and Hall's volumetric model, using } \\
\text { different algorithms. In addition, the study used the } \\
\text { ANN methodology in the eucalyptus species, as a } \\
\text { DBH function, for volume estimation. }\end{array}$ & $\begin{array}{l}\text { 18 Networks: } 10 \text { MLP and } 8 \text { RBF } \\
\text { networks }\end{array}$ & $\begin{array}{l}\text { "lnputs: } 9 \text { Networks considering DAP }(4.5 \text { to } 28.3 \\
\text { centimeters) and Total Height (6.6 to } 33.8 \text { meters) and } \\
\text { other 9 Network with DAि (4.5 to } 28.3 \text { centimeters, } \\
\text { Total Height (6.6 to } 33.8 \text { meters) and Clone. } \\
\text { Output: Volume. }\end{array}$ \\
\hline $\begin{array}{l}\text { Diamantopoulou } \\
\text { \& Milios (2010) }\end{array}$ & $\begin{array}{l}\text { The authors proposed to describe an ANN } \\
\text { modeling to estimate the total volume of dominant } \\
\text { Pinus ( } P \text { inus brutia) inside/outside the tree trunk in } \\
\text { reforestation. }\end{array}$ & $\begin{array}{l}\text { Selection of the two best } \\
\text { networks, one for the volume } \\
\text { inside the bark and another for } \\
\text { the volume outside the bark }\end{array}$ & $\begin{array}{l}\text { "Inputs: Mean diameter inside the bark (maximum } \\
\text { and minimum), taken at two intervals }[(0,3),(1,3) \text {, } \\
\text { (3,3) and }(5,3)] \text { and the total height. On the other } \\
\text { hand, network } 2 \text { (for the volume outside the bark) } \\
\text { also had these variables; however, with changes in } \\
\text { the diameter type (calculated outside the bark). } \\
\text { Output: Total volume (inside and outside the bark)." }\end{array}$ \\
\hline
\end{tabular}
ANN models in the stemp volume estimate of four

$\begin{array}{ll}\text { Özcelik et al. } & \text { tree species. To do so, it assessed the performance } \\ (2010) & \text { of two ANN types: I) the multilayer perceptron }\end{array}$ of two ANN types: 1) the multilayer perceptron
architecture using the return propagation algorithm and 2) the CCANN architecture.

The scope was to assess the ANN capacity and a

Petropoulos et al. Spectral Angle Mapper, both combined with the

(2010)
region, in the mapping of a burned area.

The achieved proposition aimed to apply Bohart and

The achieved proposition aimed to apply Bohart and
Adams' model to display the absorption process of
textile dyes in glass pillars using Eucalyptus barks. In
addition, the study chose to make use of ANN to
determine the dye absorption capacity of the bed determine the dye absorption capacity of the bed system.

2 MLP networks and 2 CCANN for each species (total of 8
networks of each type).

"Inputs: Stub diameter, stemp height and diameter at the

Output: Stemp volume."

"Inputs: Although not specified, we can assume that the inputs are related to the burning points
An MLP network for each of the indicated in the Landsat TM satellite images.
Output: Total area burned. Each network has its predicted 5 classes analyzed Output. Total area burned. Each network has its predicted burning associated with a given class. Therefore, the sum
of all burning areas, from all classes, will inform the total of burnings that occurred in the region. Construction of two MLP
networks (one for each dye "Inputs: Volume of water, height of filtering material RB5)). and concentration of dyes per liter
Outputs: Dye concentration of treated water.

"Inputs: Measurements of diameters at three different heights, at each tree base $(0.30 \mathrm{~m}, 0.70 \mathrm{~m}$ and $1.30 \mathrm{~m})$. Note: The next step considered the output of the first case as a new input, generating $(0.7 \mathrm{~m}, 1.3 \mathrm{~m}$ and $2 \mathrm{~m})$. These steps are repeated at every $\mathrm{m}$, along the stem, until reaching the total height of the tree. Thus, we can describe the inputs in a generalized way: $d=$ diameter (di-2, di- 1 and $d i)$.

This study's scope aimed to present an approach for

Uninformed with the ANN use.

II

This study's objective was to determine the potential of integrated texture measurements with an ANN model and Multiple Linear Regression $\begin{array}{ll}\text { Lottering \& } & \text { in the estimate of the edge effect of roads in } \\ \text { adjacent forests of Eucalyptus grandis. Additionally, }\end{array}$ adjacent forests of Eucalyptus grandis. Additionally,
it investigated the use of texture measurements, calculated by multispectral and panchromatic SPOT5 images, in $\mathrm{DBH}$ pre

The study outlined the modeling of two types of ANN, the MLPs and RBFs, for diameter prediction (applying only three actual measurements taken at that the author (Soares et al. [2011 and 2013])
the Soares et al.
(2012)
theveloped, this one introduced a new restriction:
the study conducted the forecast, until the minimum marketable diameter had been reached, that is, the top with $4 \mathrm{~cm}$ off the bark. In addition, it made some comparisons between the two networks, debating on which presented the best results.

This study aimed at the construction and assessment of a cellular automata model, whose evolution rule was based on artificial neura networks, for the projection of diameters distribution in eucalyptus stands.
The study trained 5 MLP networks for the forest structural measurement with the same
meature measurement with the same
architecture, differing only in the output type.

"Inputs: DBH, height of trees, basal area, volume and leaf area indexes. It is also worth mentioning that the study. associated each variable with a texture measure: $\mathrm{DBH}$ :
3 measurements; volume: 2 measurements; height: 3 measurements; basal area: 3 measurements; foliar area index: 4 measurements.

Outputs: Structural attributes of the forest and texture measurement (roadside effect).

"Inputs: Measurements of diameters at three different heights at each tree base $(0.30 \mathrm{~m}, 0.70 \mathrm{~m}$ and $1.30 \mathrm{~m})$. Note: The next step considered the output of the first case as a
5 MLP networks and 5 RBF networks. new input, generating $(0.7 \mathrm{~m}, 1.3 \mathrm{~m}$ and $2 \mathrm{~m})$. These steps are repeated every Im along the stem until reaching the total height of the tree. Thus, we can describe the inputs in a generalized way: $d=$ diameter (di-2, di- $I$ and di).
Output: Future diameter following the time series di + I"
Initially, the study comprised the construction of 50 networks. However, the work selected the top 10 , which were eventually used.
"Inputs: Current state of the cell, state of the cells in the extension of its neighborhood and the ages (current and future).
Output: Future State of the Cell." 
TABLE 4 Detailed description of relevant data/information regarding the survey of the 43 articles selected by the sample.

\begin{tabular}{|c|c|c|c|}
\hline Publication & Intended Purpose(s) & $\begin{array}{l}\text { Number of networks that authors } \\
\text { have implemented }\end{array}$ & Identification of the Network Inputs and Outputs \\
\hline Binoti et al. (20|3b) & $\begin{array}{l}\text { "This study's essence aimed at increasing the } \\
\text { accuracy of tree height estimates and, at the } \\
\text { same time, reducing the need for field height } \\
\text { measurement, in order to decrease the forest } \\
\text { inventory costs (from the construction and } \\
\text { validation of a ANN model). }\end{array}$ & $\begin{array}{l}4 \mathrm{MLP} \text { networks for scenario A } \\
\text { (introduction of a new genetic } \\
\text { material with no information } \\
\text { regarding the hypsometric } \\
\text { relation) and I } 5 \text { MLP networks } \\
\text { for scenario B (knowing the } \\
\text { growth tendency in height of the } \\
\text { stands implanted, based on the } \\
\text { measurements of the CFI). }\end{array}$ & $\begin{array}{l}\text { "Inputs: Quantitative variables: mean dominant height of } \\
\text { the plot, diameter (with bark) at I,30 m height (DBH) and } \\
\text { age. Qualitative variables: only the soil. } \\
\text { Output: Eucalyptus Final Height. }\end{array}$ \\
\hline
\end{tabular}

"Training of 500 networks for the This article aimed at assessing and comparing estimate of mortality probability; two categories of growth and production

Castro et al. (2013) using simultaneous equations and $\mathrm{ANN}$. models in commercial Eucalyptus plantations
500 networks for total height prediction at future age; 500 networks for the $\mathrm{DBH}$ prognosis in the future age."
"Inputs: Each of the 15 networks suffered variations in the variables number and type, as follows: current and future age (II and I2), site index (S), DBH class (CLA), independent competition index of distance (IIDI, IID2, IID3, IID4, IID5), the current age DBH (DBHI) and the total height at the current age $(\mathrm{hl})$.

Output: Each ANN had a possibility associated with its output: mortality probability, DBH at future age or total height at future age."

This study's purpose was to conduct a comparative work (among several methods) to obtain height predictions in sample plots of Crimerian juniper, located in the southern region of Turkey. For this, this work used several nonlinear growth functions, adjusted using nonlinear mixed-effect modeling techniques, as well as generalized models of the h-d type (height diameter measures) and ANN

The work developed an approach for the use of MLP networks, for the recursive prediction of tree diameters, with the use of only three real measurements taken at the base of the tree, without prior knowledge of the total height. Then, the predicted diameters were used with the Smalian method, in order to calculate the volume of trees in a planted location.

Considering the high cost for tree cubing in forest companies, this study's objective was to propose a methodology with the ANN volumetric equations.
2 MLP networks. breast height $(\mathrm{DBH})$ and Network II, with the same DBH, but taking into account the variation found for each plot analyzed. Output: Final height."

"Inputs: Measurements of diameters at three different heights at the base of each tree $(0.30 \mathrm{~m}, 0.70 \mathrm{~m}$ and $1.30 \mathrm{~m})$ Note: The next step considered the first case output as a new input, generating $(0.7 \mathrm{~m}, 1.3 \mathrm{~m}$ and $2 \mathrm{~m})$. These steps are repeated every $\mathrm{Im}$ along the stem until reaching the total height of the tree. Thus, we can describe the inputs, in a generalized way: $\mathrm{d}=$ diameter $(\mathrm{di}-2, \mathrm{di}-\mathrm{I}$ and $\mathrm{di})$. Output: Future diameter following the time series di + I."

"Inputs: DBH, height and diameters in positions 0,0; 0.5; I.0; I.5; 2.0; and $4.0 \mathrm{~m}$ from the soil, besides the volumes obtained from 2 to $4 \mathrm{~m}$ and the categorical variable defined

4 MLP networks.

$$
\begin{aligned}
& \text { as clone, which presents I5 subdivisions }(\mathrm{Cl} \text { to } \mathrm{CI} \text { ). } \\
& \text { Output: Volume." }
\end{aligned}
$$

Binoti et al. (2014a) $\begin{gathered}\text { to propose a methodology with the ANN } \\ \text { use, in order to reduce the number of trees } \\ \text { to be scaled during the generation process of }\end{gathered}$

Binoti et al. (2014a) $\begin{gathered}\text { to propose a methodology with the ANN } \\ \text { use, in order to reduce the number of trees } \\ \text { to be scaled during the generation process of }\end{gathered}$

"Inputs: Parameter $\beta$ of the Weibull function, initial age, future age, parameter $\gamma$ of the Weibull function, mean diameter, minimum height, dominant height, mean height,

The work proposed the ANN development and assessment in the projection of Weibull

Binoti et al. (2014b) distribution parameters and in the comparison models commonly used in the forest area.
100 MLP networks developed. However, the study selected the top 16 networks. maximum height, minimum $\mathrm{DBH}$ mean $\mathrm{DBH}$, maximum height, minimum $\mathrm{DBH}$, mean $\mathrm{DBH}$

Output: The first four networks worked with the parameter $\beta$ of the Weibull function in the future age Networks 5 to 8 predicted the parameter $\square$ of the Weibull function in the future age; Networks 9 to 12 completed the minimum $\mathrm{DBH}$ prognosis at future age and the last 4 networks estimated maximum DBH at future age."

"Inputs: 4 NDVI values obtained through Landsat TM images, average reflectance of objects in each of the 5 bands, total brightness, contribution rate of a given band to the general brightness (bands 4 and 5), maximum difference between the mean intensities of each band, for the creation of a use and land coverage map in the northern region of the State of Minas Gerais. For this, it outlined three specific objectives: to test the use of image segmentation techniques for an object-based Silva et al. (2014) classification, contemplating spectral, spatial Development of IO MLP and temporal information; to test the use of high spatial resolution images (Rapideye) combined with time series Landsat-TM, aiming at capturing the seasonality effects; and the classification of the data through ANN average difference between the pixel values of the objects (bands 4 and 5) and standard deviation (bands 4 and 5). Outputs: Each neuron represents a type of native class, as follows: Agricultural land (I), water (2), cerrado (3), deciduous forest (4), eucalyptus (5), others (6), pastures (7)

This study turned to the construction of a simple growth and yield model that has the capacity to predict the growth of individual trees under different climate change scenarios.

Ashraf et al. (2015)

These data come from the integration of historical records, ecological processes, JABOWA-3 (responsible for designing tree growth in different climate change scenarios) and ANN.

The main objective aimed at assessing the

ANN methodology for the prediction of wood 8 MLP networks segmented into

Bhering et al. (2015) volume in eucalypt breeding programs and in the selection of families, comparing their results with those that the regression model found. 4 networks, for conditions at 3
years of age, and 4 networks for 6 years

$$
\text { and track (8)." }
$$

"Inputs: basal area, sum of total stands of softwood (SW) basal area in the PSP, total stands of basal area of finewoods or hardwoods (HW) in the PSP, basal area sum of SW-type large trees (based on the diameter) in a PSP, basal area sum of large HW trees (based on the diameter) in a PSP, dominant height, soil moisture, soil nutrients, species class identification, stock factor, days of increasing degree, solar radiation and climatic scenarios. Outputs: Volume increase and basal area."

"Inputs: Situation A: total diameter and height; Situation B: commercial diameter and height; Situation C: types of species, total diameter and height (both for total volume) and commercial diameter and

height (used for commercial volume calculation). Output: Volume."

To continue... 
TABLE 4 Detailed description of relevant data/information regarding the survey of the 43 articles selected by the sample.

\begin{tabular}{cc}
\hline Publication & Intended Purpose(s) \\
\hline Binoti et al (2015) & $\begin{array}{c}\text { The study's focus was to model not only the } \\
\text { volumetric production of Eucalyptus clone } \\
\text { stands in function of categorical and numerical } \\
\text { variables, but also to evaluate the accuracy of }\end{array}$ \\
ANN prognosis.
\end{tabular}

Number of networks that authors have implemented

"The work trained 600 networks

to prognose the basal area: 200 "Inputs: Categorical (for basal area): design, soil type, relief, perceptrons, 200 MLPs and 200

perceptrons, 200 MLPs and 200

RBFs. Analogously, the same
applies to the volume forecast,

that is, 600 networks divided

into the three types of networks

presented (200 each).

However, the work considered

the best 24 networks for the

discussion of the results ( 12 as

basal area and 12 as volume)."

The objective was to compare the results Cosenza et al. (2015) $\begin{gathered}\text { obtained by the forest data processing, with the } \\ \text { Support Vector Machine and ANN, aiming to }\end{gathered}$ classify the productive capacity of eucalyptus stands.
Preliminarily, the study considered the training of 400 networks with different 400 networks with different
configurations. After this process, it selected the 5 best RBF networks, being 4 MLP and I
Identification of the Network Inputs and Outputs current age, future age and current basal area. Categorical (for volume): design, soil type, relief, texture, clone and spacing. Numerical (for volume): current age, future age, current basal area, initial volume and future basal area. Outputs: An output for the first set of networks: basal area.

An output for the second set of networks: future volume.

This happens because the future basal area is treated as

"Inputs: The soil and preparation type before planting; the spacing used; the stand age; dominant height; basal area; volume with bark; diameter at I,3m of height (DBH), minimum, average and maximum of the stand, and the

number of individuals per hectare. Within these categorical variables, ten types of soils, two types of soil preparation and five types of spacing were described.

Output: The value emitted by each of the three neurons of the output layer will represent the probability of a given field belonging to its respective class. input for the volume forecast."

\section{The article investigated the potential for improvement in the diameter distribution modeling, at a time when ANN models (with \\ Diamantopoulou et al. Levenberg-Marquardt learning) were used as an (2015) internal procedure to accurately estimate the parameters required in the Weibull distribution modeling of two parameters, using the Method \\ of Moments (MOM) and the Maximum} Likelihood Estimation (MLE).

\section{The proposal consisted of the construction of alternative forecast models for the proportion of planned final products that can be extracted \\ Hickey et al. (2015) from a forest compartment. For this, the study ANN to compare their respective results with a multivariate model of multiple regression benchmark. \\ This study's objective was to assess the regression analysis effectiveness and ANN \\ Miguel et al. (2015) $\begin{gathered}\text { models in the prediction of the amount of wood } \\ \text { and biomass above the soil, of the arboreal }\end{gathered}$ vegetation in an area composed of the cerrado biome, known as "cerradão". \\ The authors sought to investigate the potential of L-band SAR (ALOS/PALSAR) and C-band (ENVISAT/ASAR) images in the monitoring of Santi et al. (2015) forest biomass and, simultaneously, to develop a recovery algorithm based on ANN to estimate the wood volume the combined acquisitions of satellite images.}

3 LMANN networks (Neural Networks with LevenbergMarquardt learning)
"Inputs: Tree age, mean square diameter and basal area. Output: Diameter distribution."
Only one MLP network constructed with the aid of three heuristics, in order to obtain the best topology.
The study counted on the development of 400 networks.
However, from this added value However, from this added value,
the authors configured 100 networks for each of the fou selected outputs.
"Inputs: Mean diameter at breast height, first thinning harvest, second thinning harvest, SS/NS species and LP/ LPS/OC species (both uninformed about what they mean) and elevation.

Outputs: Sawlog ratio (size suitable for sawing wood, processed in sawmills); proportion of wood pallets; proportion of wood stakes; Proportion of wood pulp."

"Inputs: Basal area (G); Enhanced Vegetation Index Modified (EVI2); Normalized Difference Vegetation Index

(NDVI); Soil Adjusted Vegetation Index (SAVI) and the simple ratio vegetation index (SR).

Output: Total volume, stem volume, total biomass or stem biomass."

"Scenario for area A: 4 MLP

networks considering the input

data generated by: PALSAR

4 inches, PALSAR ( $\mathrm{HH}, \mathrm{HV})$,

PALSAR 2 Inches + ASAR and

PALSAR 4 inches + ASAR.

Scenario for area B: 2 MLP

networks considering all image

data (ALOS/PALSAR and

ENVISAT/ASAR)."

"Inputs: Acquisitions of available frequencies and polarizations intermediated by RAS, in addition to the incidence angles and an auxiliary database. Output: Volume."

\begin{tabular}{c}
\hline The proposal considered the analysis of the \\
environmental variables that act in the litter \\
formation in a gallery forest through the \\
application of the ANN methodology.
\end{tabular}

Initially, the work developed 500 MLP networks. However, it selected the best 3 ones to continue the experiment.
"Inputs: Elevation, spatial position ( $x$ and $y$ coordinate in UTM), monthly accumulated rainfall data, number of rainy days, maximum and minimum temperatures, average temperature, average relative air humidity, average atmospheric pressure, average rainfall, average wind speed, number of individuals and species per plot, Shannon Weaver diversity index and number of individuals from the most representative families.

Outputs: Leaf fractions; Branch fractions (branches and barks); reproductive structures and total litter in grams."
The study involved the basic density modeling of wood for Eucalyptus clones as a function of numerical variables obtained by $\mathrm{CFI}$

Leite et al. (2016) with the ANN use under different training standpoints: Error backpropagation, resilient propagation, Manhattan update rule, scaled conjugate gradient, levenberg marquardt, quick propagation and the SA and GA metaheuristics.
Training of $4.16 \times 10^{\wedge} 12$ and test of $4.16 \times 10^{\wedge} 10 \mathrm{MLP}$ networks according to the various combinations of the number of neurons, training algorithms and activation functions.
"Inputs: Age (years); basal area $\left(\mathrm{m}^{2} / \mathrm{ha}\right)$; annual average increase $\left(\mathrm{m}^{3} /\right.$ ha/year $)$ at the measurement age; total height $(\mathrm{m})$; diameter at $1.3 \mathrm{~m}$ from the soil surface $(\mathrm{DBH})$; number of stems per hectare $(\mathrm{n} / \mathrm{ha})$ and the ratio between $\mathrm{DBH}$ and total height. Output: Density." 
TABLE 4 Detailed description of relevant data/information regarding the survey of the 43 articles selected by the sample.

\begin{tabular}{|c|c|c|c|}
\hline Publication & Intended Purpose(s) & $\begin{array}{c}\text { Number of networks that authors } \\
\text { have implemented }\end{array}$ & Identification of the Network Inputs and Outputs \\
\hline Martins et al. (2016) & $\begin{array}{l}\text { The study's scope consisted in defining the } \\
\text { appropriate ANN configurations to obtain the } \\
\text { total height of eucalyptus trees, taking into } \\
\text { account different training methods, among } \\
\text { them: the Manhattan Update Rule, Scaled } \\
\text { Conjugate Gradient, Levenberg Marquardt and } \\
\text { two meta- heuristics, Genetic Algorithm and }\end{array}$ & $\begin{array}{l}1.2 \times 10^{\wedge} 6 \mathrm{MLP} \text { networks } \\
\text { tested through a script } \\
\text { containing all configurations. }\end{array}$ & $\begin{array}{c}\text { "The inputs included the use of quantitative (diameter at } \\
\text { breast height, dominant height and age) and categorical } \\
\text { (project, clone, soil type, spacing and terrain, respectively, } \\
4,6,15 \text { and } 6 \text { classes) variables. } \\
\text { Output: Total height of Eucalyptus trees." }\end{array}$ \\
\hline
\end{tabular}

This study's alignment included the assessment of the abilities of ANN models and the RF technique in the prognosis of the tree diameter, at any height and accumulated volume, along

Nunes \& Gorgens the length of the stem (depending on the (2016) measurement of the tree conicity), in three different regions: the cerrado, a tropical forest and a semi-deciduous forest. At the end, the study compared these results with a specific model of taper equation.

The study's purpose was to model the
projection of the future diameter of individual
trees in a forest managed in the Amazon,
using ANN as a source of subsidy for decision-
making.

This study's guidelines aimed at the application and assessment of the regression methods, based on the expansion of the Schumacher Ribeiro et al. (2016) model and on ANN for the estimate of stem volume and branches in the Tapajós National Forest.

\author{
I network for the volume \\ forecast and another for the \\ diameter prognosis.
}

"Inputs: Diameter at breast height, total height and three categorical "dummy" variables that represent the forest type of each of the scenarios studied (cerrado, tropical forest and semideciduous).

Outputs: Volume and diameter."
The study developed I 200 MLP networks, subdivided according to the competition index assessed. That is, 300 networks for each index (I, 2 and 3 ) and 300 networks that did not consider it.
"Inputs: Semi-independent distance competition index, diameter measured at $1.30 \mathrm{~m}$ from the soil, forest class, growth group, trunk identification class, liana infestation intensity and crown illumination.

Output: Annual periodical increment of diameter."
The authors did not report the total number of networks.
"Inputs: The work unit, type of species, DBH, commercial height and a dummy variable ( 0 for the stem volume and I for the volume of branches)

Output: Volume of stems and branches."
This study's objective was to assess the Neuroevolution of Augmenting Topologies (NEAT) method for adjusting the weights and the ANN topology, in the height estimate of clonal eucalypt stands, as well as to compare their predictions with the estimates found by a hypsometric regression model. 60 Neural Networks coded by
the NEAT method.
"Inputs: Diameter adjusted to I,3m high (DBH) and dominant height $(\mathrm{Hd})$. Output: Total height."
"Binoti et a
(2017)"
This study's objective was to evaluate the ANN for the classification of Eucalyptus plantation sites (based on silvicultural and environmental

Cosenza et al. (2017) information), in order to answer two questions: to find the best network configuration for site classification and to know if the RNA approach, without stand feature as input, was more accurate than the guide-curve method.
Initially, the work created 200 MLP networks, but only one network for each classification type (the best one) was chosen for analysis, totaling 2 networks.
"Inputs: Genetic material, spacing, rotation, soil type and climatic information. According to the authors, they considered I 7 soil types, 49 genotypes, 8 spacings and II different climate conditions.

Outputs: The network with 3 classes presented 3 neurons at the output. For this case, the mapping classification of the area had amplitudes of $5.5 \mathrm{~m}(32-37.5 \mathrm{~m}, 26.5-31.9 \mathrm{~m}$ and $2 \mathrm{I}-26.4 \mathrm{~m}$ ). On the other hand, the network with 4 classes had 4 neurons in the output. Similar to the first case, the mapping classification of the area had amplitudes, however, with values equivalent to $4.0 \mathrm{~m}$ : (33 - 37m, 29 $32.9 \mathrm{~m}, 25-28.9 \mathrm{~m}$ and $21-24.9 \mathrm{~m})$. In other words, the output refers to the site classification based on the site index observed in the different classes with amplitude variation."

"Inputs: Situation A: total diameter and height; Situation B: commercial diameter and height; Situation C: types of
This study's essence was to portray that the use of ANN can be seen as a highly feasible tool to estimate the volume of trees, considering

Lacerda et al. (2017) different species of the Brazilian savanna. As a complement, it created comparisons between the estimates of the networks with some volumetric equations. species, commercial and total diameter, as well as total and commercial height.

Outputs: Situation A: total volume; situation B: commercial volume and situation C: total volume (commercial + total)."

6 MLP Networks.

This paper aimed at assessing and comparing the ANN modeling with the regression

Vendruscolo et al. (2017) technique, regarding the total height estimate of Tectona grandis trees at different distances in the city of Cáceres, MT, Brazil.
"Inputs: diameter at breast height (DBH), plus maximum

5 MLP networks.
Output: Total height." 
TABLE 4 Detailed description of relevant data/information regarding the survey of the 43 articles selected by the sample.

\begin{tabular}{|c|c|c|c|}
\hline Publication & Intended Purpose(s) & $\begin{array}{c}\text { Number of networks that authors } \\
\text { have implemented }\end{array}$ & Identification of the Network Inputs and Outputs \\
\hline $\begin{array}{l}\text { Çatal \&Saplioğlu } \\
\qquad(2018)\end{array}$ & $\begin{array}{l}\text { The study analyzed which method could } \\
\text { correctly determine the amount of bark in } \\
\text { Pinus brutia ten., in a region of Turkey. The } \\
\text { idea was to focus on the construction of ANN } \\
\text { models and a NeuroFuzzy adaptive inference } \\
\text { system, as an alternative to the nonlinear } \\
\text { regression model. }\end{array}$ & $\begin{array}{l}\text { One MLP network and one with } \\
\text { Fuzzy logic }\end{array}$ & $\begin{array}{c}\text { "Inputs: Diameter at breast height with bark, diameter at } \\
\text { breast height without bark and volume of the tree with } \\
\text { bark. } \\
\text { Output: Bark volume. } \\
\text { " }\end{array}$ \\
\hline
\end{tabular}

\begin{tabular}{|c|c|c|c|}
\hline Reis et al. (2018a) & $\begin{array}{l}\text { The purpose was to estimate the survival and } \\
\text { mortality of individual trees in a selectively } \\
\text { harvested forest, from the ANN use (as a } \\
\text { source of subsidy) for silvicultural decisions on } \\
\text { forest management in the Amazon. }\end{array}$ & $\begin{array}{l}\text { I } 200 \text { MLP networks stratified } \\
\text { into } 4 \text { compositions each one } \\
\text { containing } 300 \text { architectures. }\end{array}$ & $\begin{array}{l}\text { "Inputs: Diameter at breast height, forest class, trunk } \\
\text { identification class, competition index, growth groups, liana } \\
\text { infestation intensity, crown illumination, lesions (or not) in } \\
\text { trees and tree rot. } \\
\text { Outputs: Mortality and Survival." }\end{array}$ \\
\hline Reis et al. (20।8b) & $\begin{array}{l}\text { The work had the proposal of using the cellular } \\
\text { automata, as a rule of evolution in ANN, to } \\
\text { design the distribution of diameters in harvested } \\
\text { forest, and could serve as a decision-making for } \\
\text { sustainable Forest Management in the Brazilian } \\
\text { Amazon. }\end{array}$ & $\begin{array}{l}\text { Initially, the study counted on } \\
\text { the creation of } 300 \text { networks; } \\
\text { however, it selected only the } 5 \\
\text { best ones.s. }\end{array}$ & $\begin{array}{l}\text { "Inputs: Current density, future density and the } \\
\text { measurement period (in years). } \\
\text { Output: Diametric distribution." }\end{array}$ \\
\hline Sanquetta et al. (20I8) & $\begin{array}{l}\text { The article sought to examine the performance } \\
\text { of some Artificial Intelligence models } \\
\text { (k-neighbors variant, one and three nearest } \\
\text { neighbors and ANN) in estimating the tradable } \\
\text { volume of Cryptomeria japonica logs in an } \\
\text { experimental plantation in southern Brazil. }\end{array}$ & Training of 450 MLP-networks & $\begin{array}{l}\text { "Inputs: Not informed. } \\
\text { Output: Total volume." }\end{array}$ \\
\hline Vieira et al. (2018) & $\begin{array}{l}\text { Considering the Artificial Intelligence potential } \\
\text { in forest measurement, this article proposed } \\
\text { the application of ANN and a fuzzy inference } \\
\text { system (ANFIS) to predict the growth in DBH } \\
\text { and the Eucalyptus height. }\end{array}$ & $\begin{array}{l}\text { Although } 100 \text { trained networks, } \\
\text { the experiment had } 8 \text { MLP and } \\
6 \text { ANFIS. }\end{array}$ & $\begin{array}{l}\text { "Inputs: Current diameter at I.30 m (DBH), future age, } \\
\text { current age, competition index (regardless of distance), } \\
\text { genetic material, site index and current total height. } \\
\text { One output per network, and can be directed to the future } \\
\text { growth in DBH or future height." }\end{array}$ \\
\hline
\end{tabular}

Legend: ANN (Artificial Neural Networks); DBH (Diameter at Breast Height); LAl (Leaf Area Index); SAR (Synthetic Aperture Radar); ENVISAT (Environmental Satellite); ASAR (Advanced Synthetic Aperture Radar); ALOS (Advanced Land Observing Satellite); PALSAR (Phased Array type L-band Synthetic Aperture Radar); MLP (Multilayer Perceptron); RBF (Radial Basis Function); CFI (Continuous Forest Inventory); CCANN (Cascade Correlation Artificial Neural Network); SAR (Synthetic Aperture Radar); SA (Simulated Annealing); GA (Algorithm Genetic); RF (Random Forest); NVDI (Normalized Difference Vegetation Index); EVI (Enhanced Vegetation Index); SAVI (Soil-adjusted vegetation index); SRVI (Simple Ratio Vegetation Index); MOM (Method of Moments); MLE( Maximum Likelihood Estimation); LMANN (Levenberg- Marquardt Artificial Neural Network); NEAT (Neuroevolution of Augmenting Topologies); LM (Levenberg - Marquardt); SCG (Scaled Conjugate Gradient); MUR (Manhattan update rule); RP (Resilient Propagation); ANFIS (Adaptative Network based Fuzzy Inference Systems); RMSE (Root Mean Square Error); GC (Guide curve); Al (Artificial Intelligence); ITM (Individual Tree Models); SAM (Spectral Angle Mapper); Landsat (Land Remote Sensing Satellite); PSP (Permanent Sample Plots).

It should be highlighted that a justification for the MLP model being more widespread and used in the literature is that the architecture of this network is considered a "universal approximator". In other words, it is a general purpose model that can be applied on a large scale (ranging from linear to non-linear problems with high complexity). Other justifications are that it is easy to use (not requiring much knowledge of the functions that will be modeled) and has been proved efficient in many studies covering a wide range of areas of expertise. On the other hand, the majority of the authors opted to make comparisons of MLP with the traditional forecasting techniques most used by forest science researchers, as is the case of regression. The idea was generally to verify which of the approaches presents a better accuracy for the output variables (mainly volume).

The Brazilian researchers who stood out during the period in question were those from the Federal University of Viçosa (8 publications). The authors (cited here individually and in chronological order) were: Silva (2009);
Binoti (20I3a); Binoti (20I3b); Bhering (20I5); Cosenza (20I5); Leite (20I6); Reis (20I6) and Binoti (20I7). The themes addressed in their studies were eucalyptus clone plantation sites (7 publications) and managed forests in the Amazon (I publication), as shown in Table 3.

As a consequence of the information stratification, the synthesis of conclusions indicated that ANNs are capable of safely predicting the different parameters of the fields of biometrics and forest modeling (considering the low indexes found by the validation metrics) and, therefore, it can be considered a very promising alternative technique. Suggestions for future studies include applying ANN to other forest problems and using other types of ANN to maximize the accuracies involved in each problem.

\section{REFERENCES}

AGUIAR, F. G. Utilização de Redes Neurais Artificiais para detecção de padrões de vazamento em dutos. Dissertação (Mestrado em Engenharia Mecânica) Universidade de São Carlos, São Carlos, SP, 2010. 
ALMEIDA, A. D. Comparação entre métodos para roteamento de redes de dados usando Redes Neurais Artificiais. Dissertação (Mestrado em Ciência da Computação) - Universidade Federal de Santa Catarina. Florianópolis, SC, 200I.

AQUINO, P.S.R.; RODRIGUES, M.S.; CASTRO, R.V.O., NAPPO, M.E. Use of artificial neural network in the analysis of environmental variables associated to litterfall. Comunicata Scientiae, v.7, n.3, p.394-405, 2016.

ASHRAF, M.I.; MENG, F.R.; BOURQUE, C.P.A.; MACLEAN, D.A.; BOND-LAMBERTY, B. A novel modelling approach for predicting forest growth and yield under climate change. PLoS ONE, v. I0, n.7, 2015.

BALCI, B.; KESKINKAN, O.; AVCI, M. Use of BDST and an ANN model for prediction of dye adsorption efficiency of Eucalyptus camaldulensis barks in fixed-bed system. Expert Systems with Applications, v.38, n. I, p.949-956, 201 I.

BHERING, L.L.; CRUZ, C.D.; PEIXOTO, L.A.; ROSADO, A.M.; LAVIOLA, B.G.; NASCIMENTO, M. Application of neural networks to predict volume in eucalyptus. Crop Breeding and Applied Biotechnology, v. 15, n.3, p. 125 |3|, 2015.

BINOTI, M.L.M.S.; BINOTI, D.H.B.; LEITE, H.G. Application of artificial neural networks to estimate the height of evenaged stands of eucalyptus. Revista Árvore, v.37, n.4, p.639-645, 2013.

BINOTI, D.H.B.; BINOTI, M.L.M.S.; LEITE, H.G.; DA SILVA, A.A.L.; ALBUQUERQUE, A.C.An approach to diameter distribution modeling using Cellular Automata and Artificial Neural. Cerne, v.19, n.4, p.677-685, 2013.

BINOTI, M.L.M.S.; BINOTI, D.H.B.; LEITE, H.G.; GARCIA, S.L.R.; FERREIRA, M.Z.; RODE, R.; DA SILVA, A.A.L. Neural networks for estimating of the volume of trees. Revista Árvore, v.38, n.2, p.283-288, 2014.

BINOTI, M.L.M.S.; BINOTI, D.H.B.; LEITE, H.G.; DA SILVA, A.A.L.; PONTES, C. Use of artificial neural network for diameter distribution modelling for even-aged population. Revista Árvore, v.38, n.4, p.747-754, 2014.

BINOTI, M.L.M.S.; LEITE, H.G.; BINOTI, D.H.B.; GLERIANI, J.M. Stand-level prognosis of eucalyptus clones using artificial neural networks. Cerne, v.2I, n. I, p.97-105, 2015.

BINOTI, D.H.B.; DUARTE, P.j.; BINOTI, M.L.M.S.; DA SILVA, G.F.; LEITE, H.G.; MENDONÇA, A.R.; DE ANDRADE, V.C.L.; VEGA, A.E.D. Estimation of height of Eucalyptus trees with neuroevolution of Augmenting Topologies (NEAT). Revista Árvore, v.4I, n.3, 2017.

CASTRO, R.V.O.; SOARES, C.P.B.; MARTINS, F.B.; LEITE, E.H.G. Growth and yield of commercial plantations of eucalyptus estimated by two categories of models. Pesquisa Agropecuária Brasileira, v.48, n.3, p.287-295, 2013.
ÇATAL, Y.; SAPLIOĞLU, K.Comparison of adaptive neurofuzzy inference system, artificial neural networks and nonlinear regression for bark volume estimation in brutian pine (Pinus brutia ten.). Applied Ecology and Environmental Research, v.16, n.2, p.2015-2027, 2018.

COSENZA D.N.; LEITE, H.G.; MARCATTI, G.E.; BINOTI, D.H.B.; DE ALCÂNTARA, A.E.M.; RODE, R. Site classification with support vector machine and artificial neural network. Scientia Forestalis, v.43, n. I08, p.955-963, 2015.

COSENZA, D.N.; SOARES, A.A.V.; DE ALCÂNTARA, A.E.M.; DA SILVA, A.A.L.; REDE, R.; SOARES, V.P.; LEITE, H.G. Site classification for eucalypt stands using artificial neural network based on environmental and management features. Cerne, v.23, n.3, p.310-320, 2017

DIAMANTOPOULOU, M.J.; MILIOS, E.; DOGANOS, D.; BISTINAS, I. Artificial neural network modeling for reforestation design through the dominant trees bolevolume estimation. Natural Resource Modeling, v.22, n.4, p.5 I I-543, 2009.

DIAMANTOPOULOU, M.J.; MILIOS, E. Modelling total volume of dominant pine trees in reforestations via multivariate analysis and artificial neural network models. Biosystems Engineering, v. 105, p.306-315, 2010.

DIAMANTOPOULOU, M.J.; ÖZÇELIK, R.; CRECENTECAMPO, F;; ELER, T. Estimation of Weibull function parameters for modelling tree diameter distribution using least squares and artificial neural networks methods. Biosystems Engineering, v. I33, p.33-45, 2015.

FAUSETT, L. Fundamentals of Neural Networks, Prentice-Hall, Englewood Cliffs, NJ, 1994.

FREIMAN, J. P. Utilização de Redes Neurais Artificiais na previsão de indicadores financeiros para avaliação econômica de negócios em situação de risco. Dissertação (Mestrado em Engenharia de Produção) Universidade Federal de Itajubá. Itajubá, 2004.

GALVÃO T.F; PEREIRA M.G. Systematic reviews of the literature: steps for preparation. Epidemiologia e Serviços de Saúde, v. I, n.23, p. I83-184, 2015.

Gil, A.C. Como elaborar projetos de pesquisa. São Paulo: Atlas, 2002

Haykin, S. Redes neurais: princípios e prática. Porto Alegre: Bookman, 2001.

HICKEY, C.; KELLY, S.; CARROLL, P.; O'CONNOR, J. Prediction of Forestry Planned End Products Using Dirichlet Regression and Neural Networks. Forest Science, v.6I, n.2, p.289-297, 2015.

ITO, E.; ONO, K.; ITO, Y.M.; ARAKI, M. A neural network approach to simple prediction of soil nitrification potential: A case study in Japanese temperate forests. Ecological Modelling, v.219, n. I-2, p.200-2II, 2008. 
LACERDA, T.H.S.; CABACINHA, C.D.; ARAÚJO JÚNIOR, C.A.; MAIA, R.D.; LACERDA, K.W.S. Artificial neural networks for estimating tree volume in the Brazilian savanna. Cerne, v.23, n.4, p.483-49I, 2017.

LEITE, H.G.; BINOTI, D.H.B.; OLIVEIRA NETO, R.R.; LOPES, P.F; DE CASTRO, R.R.; PAULINO, E.J.; BINOTI, M.L.M.S.; COLODETTE, J.L. Artificial neural networks for basic wood density estimation. Scientia Forestalis, v.44, n. 109,:p.49-154, 2016.

LOTTERING, R.; MUTANGA, O. Estimating the road edge effect on adjacent Eucalyptus grandis forests in KwaZulu-Natal South Africa using texture measures and an artificial neural network. Journal Spatial Science, v.57, p. 153-173, 2012.

MARTINS, E.R.; BINOTI, M.L.M.S.; LEITE, H.G.; BINOTI, D.H.B.; DUTRA, G.C. Configuration of artificial neural networks for estimation of total height of eucalyptus trees. Revista Brasileira de Ciências Agrárias, v.lI, n.2, p.II7-123, 2016.

MEDEIROS I.L.; VIEIRA, A.; BRAVIANO, G.; GONÇALVES, B.S Revisão Sistemática e Bibliometria facilitadas por um Canvas para visualização de informação. Revista Brasileira de Design da Informação, São Paulo, v. I2, n. I, p. 93 - 100, 2015.

MENZIES, J.; JENSEN, R.; BRONDIZIO, E.; MORAN, E.; MAUSEL, P. Accuracy of neural network and regression leaf area estimators for the Amazon Basin. GIScience and Remote Sensing, v.44, n. I, p.82-92, 2007.

MIGUEL, E.P.; REZENDE, A.V.; LEAL, F.A.; MATRICARDI, E. A. T.; VALE, A.T.; PEREIRA, R.S. Artificial neural networks for modeling wood volume and aboveground biomass of tall Cerrado using satellite data. Pesquisa Agropecuária Brasileira, v.50, n.9, p.829-839, 2015

NUNES, M. H.; GORGENS, E. B. Artificial intelligence procedures for tree taper estimation within a complex vegetation mosaic in Brazil. PLoS ONE, v.II, n.5, p.I-16, 2016.

OLIVEIRA, V.P.L. Redes Neurais Artificiais e K-médias em um modelo híbrido alternativo para a classificação de clientes em aprovação de crédito. Universidade Federal de Goiás.Goiânia, 2015.

ÖZCCELIK, R.; DIAMANTOPOULOU, M.J.; WIANT JR., H.V.; BROOKS, J.R. Comparative study of standard and modern methods for estimating tree bole volume of three species in Turkey. Forest Products Journal, v.58, n.6, p.73-8I, 2008.

ÖZCELIK, R.; DIAMANTOPOULOU, M.J.; BROOKS, J.R.; WIANT JR., H.V. Estimating tree bole volume using artificial neural network models for four species in Turkey. Journal of Environmental Management, v.91, n.3, p.742-753, 2010.

ÖZÇELIK, R.; DIAMANTOPOULOU, M.J.; CRESCENTECAMPO, F.; ELER, U. Estimating Crimean juniper tree height using nonlinear regression and artificial neural network models. Forest Ecology and Management, v.306, n.15, p.52-60, 2013.
PETROPOULOS, G.P.; VADREVU, K.P.; XANTHOPOULOS, G.; KARANTOUNIAS, G.; SCHOLZE, M. A comparison of spectral angle mapper and artificial neural network classifiers combined with landsat TM imagery analysis for obtaining burnt area mapping. Sensors, v. 10, n.3, p.1967-1985, 2010.

REIS, L.P.; SOUZA, A.L.; MAZZEI, L.; REIS, P.C.M.; LEITE, H.G.; SOARES, C.P.B.; TORRES, C.M.M.E.; DA SILVA, L.F. Prognosis on the diameter of individual trees on the eastern region of the amazon using artificial neural networks. Forest Ecology and Management, v.382, p.16I-167, 2016.

REIS, L.P.; SOUZA, A.L.; REIS, P.C.M.; MAZZEI, L.; BINOTI, D.H.B.; LEITE, H.G. Prognosis of the diameter distribution in the Amazon by using artificial neural networks and cellular automata. Floresta, v.48, n. I, p.:93-102, 2018

REIS, L.P.; SOUZA, A.L.; REIS, P.C.M.; MAZZEI, L.; SOARES, C.P.B.; TORRES, C.M.M.E.; DA SILVA, L.F.; RUSCHEL, A.R., RÊGO, L.J.S.; LEITE, H.G. Ecological Engineering, v.II2, p.|40-147, 2018

RIBEIRO, R.B. DA S.; GAMA, J.R.V.; DE SOUZA, A.L.; LEITE, H.G.; SOARES, C.P.B.; DA SILVA, G.F. Methods to estimate the volume of stems and branches in the Tapajós national forest. Revista Árvore, v.40, n. I, p.8I-88, 2016.

RUMELHART, D.E.; HINTON, G.E.; WILLIAMS, R.J. Learning internal representations by backpropagating errors. Nature, v.323, p533-536, 1986.

SANQUETTA, C.R.; PIVA, L.R.O.; WOJCIECHOWSKI, J.; CORTE, A.P.D.; SCHIKOWSKI, A.B. Volume estimation of Cryptomeria japonica logs in southern Brazil using artificial intelligence models. Southern Forests, v.80, n. I, p.29-36, 2018.

SANTI, E.; PALOSCIA, S.; PETTINATO, S.; CHIRICI, G.; MURA, M.; MASELLI, F. Application of neural networks for the retrieval of forest woody volume from SAR multifrequency data at I and $C$ bands. European Journal of Remote Sensing, v.48, p.673-687, 2015.

SILVA, M.L.M.; BINOTI, D.H.B.; GLERIANI, J.M.; LEITE, H.G. Adjustment of the Schumacher and Hall model and application of artificial neural networks to estimate volume of eucalypt trees. Revista Arvore, v.33, n.6, p. I |4 I-I |47, 2009.

SILVA A. M. Utilização de Redes Neurais Artificiais para Classificação de SPAM. Dissertação (Mestrado em Modelagem Matemática e Computacional) - Centro Federal de Educação Tecnológica de Minas Gerais, Belo Horizonte, $\mathrm{BH}, 2009$.

SILVA, P.R.; ACERBI JÚNIOR, F.W.; DE CARVALHO, L.M.T.; SCOLFORO, J.R.S. Use of artificial neural networks and geographic objects for classifying remote sensing imagery. Cerne, v.20, n.2, p.267-276, 2014.

SOARES, F.A.A.M.N.; FLÔRES, E.L.; CABACINHA, C.D.; CARRIJO, G.A.; VEIGA, A.C.P. Recursive diameter prediction and volume calculation of eucalyptus trees using Multilayer Perceptron Networks. Computers and Electronics in Agriculture, v.78, n. I, p.19-27, 201 I. 
SOARES, F.A.A.M.N.; FLÔRES, E.L.; CABACINHA, C.D.; CARRIJO, G.A.; VEIGA, A.C.P. Recursive diameter prediction for calculating merchantable volume of Eucalyptus clones without previous knowledge of total tree height using artificial neural networks. Applied Soft Computing Journal, v. I2, n.8, p.2030-2039, 2012.

SOARES, F.A.A.M.N.; FLÔRES, E.L.; CABACINHA, C.D.; CARRIJO, G.A.; VEIGA, A.C.P. Recursive diameter prediction for calculating merchantable volume of eucalyptus clones using Multilayer Perceptron. Neural Computing and Applications, v.22, n.7-8, p.|407-|4I8, 2013.

STEINER, M.T.A.; SOMA, N.Y.; SHIMIZU, T.; NIEVOLA, J.C.; STEINER NETO, P.j. Using Neural Networks Rule Extraction for Credit-risk Evaluation. International Journal of Computer Science and Network Security, v.6, n.5 a p.6-17, 2006.
VALENTE, G.F.S.; GUIMARÃES, D.C.; GASPARDI, A.L.A.; OLIVEIRA, L.A. Aplicação de redes neurais artificiais como teste de detecção de fraude de leite por adição de soro de queijo. Instituto de Laticínios Cândido Tostes, v.69, n.6, p.425-432, 2014.

VENDRUSCOLO, D.G.S.; CHAVES, A.G.S.; MEDEIROS, R.A.; DA SILVA, R.S.; SOUZA, H.S.; DRESCHER, R.; LEITE, H.G. Height estimative of Tectona grandis L. f. trees using regression and artificial neural networks. Nativa: Pesquisas Agrárias e Ambientais, v.5, n. I, p.52-58, 2017.

VIEIRA, G.C.; DE MENDONÇA, A.R.; DA SILVA, G.F.; ZANETTI, S.; DA SILVA, M.M., DOS SANTOS, A.R. Prognoses of diameter and height of trees of eucalyptus using artificial intelligence. Science of the Total Environment, v.619-620, p.|473-1481, 2018. 